\title{
Latent Membrane Protein 1
}

National Cancer Institute

\section{Source}

National Cancer Institute. Latent Membrane Protein 1. NCI Thesaurus. Code C18863.

Latent membrane protein 1 (386 aa, $\sim 42 \mathrm{kDa}$ ) is encoded by the Epstein-Barr virus LMP1 gene. This protein is involved in both the activation of nuclear factor-kappa-B family signaling pathways and the inhibition of apoptosis of infected B-lymphocytes. 